Article

\title{
The Business Model of Start-Up-Structure and Consequences
}

\author{
Štefan Slávik (1) \\ Department of Management, University of Economics in Bratislava, 85102 Bratislava, Slovakia; \\ stefan.slavik@euba.sk
}

Received: 18 June 2019; Accepted: 5 September 2019; Published: 9 September 2019

\begin{abstract}
A start-up already at its origin has to solve the crucial existential condition that is a viable business model. The purpose of the research is to deepen and expand the knowledge about the structure of the start-up business model and its impact on entrepreneurial performance. Field research was carried out in three stages over one and a half years. The source of knowledge about the studied start-ups has been the personal experience recorded in the questionnaire. Start-ups are small closed communities that do not sufficiently shape external partnerships, cannot reach the customers, although they can identify them well enough, try to improve the business model blocks but they do not pay attention to their coordination and perceive the monetization in a simplified way. The impact of the business model on start-up performance has been confirmed but the internal blocks affect business performance unambiguously over the three stages of the research. The best conversion of users to customers and subsequently to revenues are distinctive for the start-ups with their own simple distribution channel and partners who are experienced distributors. The lessons learned can directly improve the results of start-ups when their incompleteness and imperfection will be substituted by appropriate partners. Start-ups provide a space for the new jobs and the self-realization of ambitious people with a sense of service for society. Empirical research on start-ups identifies their weaknesses and possibilities to increase their entrepreneurial performance.
\end{abstract}

Keywords: start-up; business model; canvas; business performance; conversion

\section{Introduction}

A start-up is an entrepreneurial experiment and a very small beginning enterprise that provides a space for self-realization, an opportunity to develop and implement unusual and risky ideas, an unparalleled satisfaction of existing needs and discovery of new needs. Start-ups contain the potential for exceptional growth but also unforeseen and repeated failures. They are a living laboratory to explore the emergence and maturation of an enterprise. Rapid growth, experimenting with ideas that would be too courageous for ordinary companies, high returns and quick feedback attract not only businesspeople but also researchers, to reveal and explain the functioning and perilous places of this relatively new business phenomenon. The advancement, success and survival of the start-up usually depends on the quality of its business model, team and business strategy. A model is a tool for developing, verifying and implementing an entrepreneurial idea, a team is a small social group that creates a start-up personal background and the business strategy is a manifestation of the deliberate action of a start-up in a competitive environment. Among these three determinants of entrepreneurial performance, research focuses on the role of the business model, as it is considered to be the primary assumption of the existence of a start-up. A start-up as an incomplete and imperfect enterprise has to build a business model to implement its business idea. The model contains all the components and conditions that are necessary for the operation of an enterprise. An effective business model provides 
the customer with a value the customer accepts and pays for, on the other hand, the enterprise will cover all its costs and earn a profit.

A wider and more comprehensive look at the start-up and its business model. The KPMG Research Report (KPMG 2014, p. 34) states that the start-up weaknesses are financial planning, expansion to new markets, fundraising, business modelling and other deficiencies. Investors in the next KPMG Report (KPMG 2016, p. 23) say that significant investment criteria, along with the quality of the management team, are the product and its sales potential. The research reports of European Start-up Monitor (Kollmann et al. 2015, 2016) provide formal data on start-up business models but do not address their internal structure nor explicitly investigate their impact on start-up performance. They consider them important but without further findings and conclusions. In the 2016 report (Kollmann et al. 2016, p. 3), finding a profitable and repeatable business model, scaling, sales growth and the acquisition of new customers are considered to be the greatest challenges. Similarly, the Booming Berlin report (Booming Berlin 2016, p. 9) on the Berlin start-up scene assumes that with a functioning business model, the start-up will develop into a growing enterprise over a period of up to five years.

Sedlacek and Sterk (2014), in their research study, are attentive to start-ups like a significant source of employment growth. Dent et al. (2016) examined the role of start-ups in structural transformation and their implications for employment. Fritsch and Wyrwich (2018) explored start-ups in the context of regional knowledge and entrepreneurial culture. These studies show that start-ups are a major phenomenon in the development of the economy and business. They dealt with the national economic implications of their existence and the regional causes of their nascence. These studies have not explored start-up business models and their implications for business viability.

Foss and Saebi (2017) are engaged in business model innovation (BMI) and have found interesting topics for further research such as sustainability, servitization, open innovation and dynamic capabilities. They also highlight the close interrelationship between BMI and entrepreneurship, which has not received sufficient attention to date. Service-oriented business models have received increasing attention both in the academic and managerial community. Adrodegari et al. (2018) have recorded new trends for capital goods manufacturers who push towards selling products or performance rather than the product itself. Koch (2015) noticed that in IT start-up business models their efficiency is conditioned by scarcity and personalization. Scarcity stimulates the purchase by deliberately shortening the availability of a product or service. Personalization is recognizing and treating customers as individuals through personal messaging, personalized offers or other personal transaction. Gimpel et al. (2017) analyzed consumer-oriented fintech start-ups, their offerings and monetization, which are the beginning and end of the business model. They identified archetypes of offerings via cluster analysis. Hyytinen et al. (2015) investigated whether innovation reduces the start-up survival rate. They have come to the unconventional conclusion that pursuing innovations is not necessarily associated with survival during the early stages of firm development and involves a more complicated start-up process. Groesser and Jovy (2016) consider the business model an essential part of a company-regardless of whether the company is a small entity or a global enterprise. They believe that the qualitative methods of its research fail especially in uncertain, highly volatile situations and should be substituted by computational modelling, which helps to understand business models as complex systems with dynamic interdependencies. A key interaction is the link between supply and demand. Korhonen et al. (2017) highlight the importance of attracting a large user pool, providing new services for those users, offering a new market for producers, supporting core interaction in various ways, mostly through digital platforms.

A special chapter in the research on start-ups is represented by incubators. Van Weele et al. (2016) explored interrelated challenges that constrain the ability of Western European start-ups to grow into high-impact businesses. They suggest that, rather than addressing the underlying institutions that cause challenges in the entrepreneurial ecosystem, incubators provide symptomatic solutions by creating an environment that protects start-ups from unfavorable institutions. Another result of the research was that the start-ups suffer from lack of market orientation, the lack of an entrepreneurial 
culture, a small domestic market, the lack of early-stage capital and that universities are not focused on entrepreneurship.

In the background of the sketched topics that explore the start-up business making, the common and unifying denominator, which is the business model, shines through. The business model is considered a serious condition for a successful business, it has various partial features, partial proposal for its improvement are commended or suggestions for improving start-up business making conditions. Most of the listed shortcomings arise from an imperfect business model. The positive effects of start-ups in the broader economic and business contexts are highlighted.

The key role of the business model of the start-up is emphasized by Foss and Saebi (2017) when writing, "for start-ups, any act of entrepreneurship means the choice of a business model, while in established firms the enterprise's business judgment results in changes in the business model components or architecture." Research studies, however, do not shed light on the structure and consequences of the business model of start-ups. Davila et al. (2015) draw attention that the start-up enters an established market with a business model that ex-post turns out to be economically nonviable. Kopera et al. (2018) explain that a source of success is rarely a technological superiority alone but rather a business model that stays behind. The business model supports the complex business endeavor, resulting in better product design and its business model configuration. Block et al. (2014) write that the birth conditions of a firm tend to be imprinted in firms for very long periods. Thus, early strategic decisions tend to be lasting ones. In addition, the skills, customer contacts, personnel and capital investments at start-up tend to lock the firm into its condition. It can be added that many of these conditions are clearly related to the business model. The importance of the model for start-ups is also recognized by the technology transfer office organizing intensive innovation programs for entrepreneurs developing business models (Pettersen et al. 2016).

The findings of Rydehell and Isaksson (2016) indicate that the founders of new technology-based firms (NTBFs) perceive their customer value proposition as the most valuable element of their business model. They also recognized signs of the influence of financial partners on the founders' perceptions of the initial business models. Furthermore, findings show that some NTBFs create parallel business models within their firms to ensure survival in the start-up phase. Findings of Malmström and Johansson (2017) highlight that cash and competence appear to be an essential focus in managing business model components in the early stage of new ventures. Teece and Linden (2017) write that in many cases, however, Internet-based businesses are pursuing customer growth ahead of profits. The path to profitability, which is a core element of a business model, should not be an afterthought. A well-designed business model balances the provision of value to customers with the capture of value by the provider. Klačmer Čalopa et al. (2014) came to the similar conclusion, stating, "it is difficult to find investors for a start-up which is still not yielding profit, as well as potential users." Euchner and Ganguly (2014) perceive the business model in broader contexts and consequences, saying, "the business model is not the means by which a firm creates and captures customer value. Focusing on creating customer value without regard to competitive advantage will leave a firm vulnerable to both margin erosion and anaemic growth."

The business model and/or its parts are considered to be a significant factor of start-up viability. These claims arise from common knowledge about start-ups and their business making but not confirmed by empirical/field research. The business model has a structure whose elements will likely influence the viability of the start-up to various degree. Knowing the structure of the business model and its effect on the business performance of the start-up may increase the likelihood of its survival.

\section{Current Knowledge of Start-Ups and Their Business Models-Literary Review}

A narrower and more detailed look at the start-up and its business model. P. Thiel (2014, pp. 10-11), one of the founders of PayPal, does not perceive a start-up as a precisely bounded business entity. A start-up is primarily, according to him, a community of people who have teamed up to achieve an unusual goal through extraordinary intellectual effort and unconventional corporate culture. 
Recognized business matadors Blank and Dorf describe start-ups more formally than Thiel. They write (Blank and Dorf 2012, p. XVII) that "Start-up is a temporary organization to look for a scalable, repeatable and profitable business model." Great attention is paid to scaling. According to their findings (Blank and Dorf 2012, p. XVIII), the scalable start-up is the job of traditional technology entrepreneurs. They set up a company with a vision of changing the world and their company will have a turnover of millions if not billions of dollars. A scalable start-up initially looks for a repeatable and scalable business model.

Makers of canvas visualization do not explicitly define the start-up in their latest work but aptly describe the internal affairs in this business entity (Osterwalder et al. 2014, p. XVIII): "The main challenges: to provide proof that ideas are functional even in limited budget; to attract investors (if the idea develops); the risk of spending money before finding the right customer value and business model; main opportunities: use rapid decision making and agility as an advantage; use proprietary motivation as a factor of success." It follows that a start-up is situated in constant effort to confirm its existence, it operates under very limited and dramatic conditions and it is expected to bring a result that is a product acceptance on the market and attractive return for an investor.

Ries, who introduced himself to the world of business with the concept of lean start-up, defines start-ups thus (Ries 2011, p. 27): "Start-up is a human institution designed to create a new product or service under conditions of extreme uncertainty." He chose the concept of the institution because the start-up hires creative people, co-ordinates their activities and shapes a business culture that delivers results. Novelty (innovation) is perceived widely, such as new scientific discoveries, changing the purpose and use of existing technology, inventing a new business model that uncovers the value that was hidden or it is simply transferring the product to a new site or addressing previously unserved customers. Innovation is the heart of business success. A contribution of Ries to defining start-up lies primarily in adding an unpredictable context that distinguishes start-up from a standard company.

An enterprise ceases to be a start-up (WIKIPEDIA n.d.) when it becomes a profitable or an object of merger or acquisition. Graham (Robehmed 2013), a representative of Y Combinator accelerator, says that after three years of doing business, most start-ups stop being a start-up, he couples completing the start-up phase with the acquisition by a larger company, more than 20 million $\$$ sales, more than 80 employees, more than five people in the board of directors and founders who have already sold their shares. If a start-up becomes profitable, it is likely to recede from its founding form.

Quoted statements and definitions can be summarized in a few keywords. A start-up works in an environment of uncertainty up to indeterminacy but at the same time it tries to find concrete and useful solutions, dynamically and temporarily grows without limits, employs people who renounce certainties of standard job at the expense of exciting personal growth and achievement of concrete results, it can or may not work on the base of technology and ceases to be a start-up after crossing certain borders (acquisition, revenue, profit, number of employees and others). Start-up from a regular SME distinguishes (Ako podporit' startupový ekosystém na Slovensku 2015) a unique and innovative product with the potential for dynamic and global growth with a prerequisite for revenues of several tens of millions euros.

The failure of start-ups is a natural phenomenon and occurs in every business and every business form. A certain number of start-up failures is even considered a positive phenomenon, as it is a mark of expended effort, gained experiences, willingness to take a risk and the ability to absorb failure and repeatedly proceed. American private information Agency CB Insights has published a study (CB Insights 2016) on the causes of start-up failures and has compiled the order of the most common causes of unsuccessful business making. The most frequent causes of failure are doing business without demand, exhaustion of cash for an operation of start-up, a non-cooperative team, smarter competition, incorrect determination of cost and prices and finally a malfunctioning business model. Most failures have a common denominator in a non-performing and low-functional business model.

The business model is usually visualized for clearness and ease of use. Afuah $(2014$, p. 5) offers one of the less complex visualizations. The content of the model is customer value proposition, resources 
and activities, market segments, growth model and yield model. An essential contribution of this concept (Afuah 2014, p. 25) is that the profit potential of the business model is evaluated by a set of VARIM criteria (value, adaptability, rareness, imitability, monetization).

The business model by Johnson et al. (2008) consists of four interconnected elements that make up and provide value. Its main parts are the customer value proposition, considered to be the most important, key resources, key processes and profit formula. The model particularly highlights the knowledge that companies are not successful with a radically new product offer if they do not understand exactly consistency between an opportunity and their business model and they do not correct this fact.

Gassmann et al. (2014, p. 7) have compiled a concept arranged into a triangle consisting of four dimensions (three vertices and center) that are customer, value proposition, value chain and profitable mechanism. Visualization is relatively simple and therefore is more appropriate than a tool for workshops than for complex systematization.

The most widespread visualization of the business model is the concept of the canvas by Osterwalder and Pigneur (2009, pp. 15-44). It contains nine blocks-customer value proposition, customer segments, customer relationships, distribution channels, key processes, key resources, key partners, costs structure and revenue streams. This model is sufficiently apt, has a larger but limited detailedness and therefore has been used in field research as well.

The meaning and usefulness of the business model are confirmed by Blank and Dorf (2012, pp. 8-18) when they write "... the only goal of the start-up is to find a repeatable and scalable business model." While existing companies pursue a business model, so start-ups look for it. This difference is, according to Blank (2013), the core of a lean method that concentrates on three principles:

1. Instead of a complicated business plan, entrepreneurs summarize their hypotheses in the concept of the canvas business model (Osterwalder and Pigneur 2009, pp. 15-44).

2. The entrepreneur enters the field, carries out customer development and tests hypotheses. After taking into account customer remarks, a review of assumptions and making small (iteration) or more substantial adjustments (pivots) follow.

3. Lean star-up practices agile development, thus an iterative and incremental development of a product in line with customer development in short repetitive cycles. Start-up makes a minimum viable product that has only a few key features and serves to gain feedback from customers.

Start-uppers have a very strong tendency to prefer an idea to the business model because they are captivated by its exceptionality and rarity which obscures the fact that even seemingly routine processes, for example, manufacturing realization and sales require adaptation, innovation, ingenuity and persistence when finding a way for the customer. Truban is a successful IT entrepreneur in Slovakia who writes in his status on Facebook (Truban 2016) that the idea is of little value and is never unique. In the discussion, he adds that the true value of a company resides in the business model. Although the revelation or creation of a profit opportunity is a top business performance, only the overall perception of a business through the business model will bring a spotted or created idea to fruition. The business model forces to perceive ideas and opportunities through the eyes of the customer and to assess their realization possibilities. The majority of start-up failures just reside in the underestimation of the business model, its imperfection or even unknowingness.

However, Teece (2018) makes a remark that business models are rarely successful for the first time and must be gently tuned and sometimes even completely rebuilt before they become profitable engines. Start-ups generally find transformation easier than do mature firms because they have fewer established assets and procedures to re-engineer.

Business performance of start-up is a criterion of its functionality and efficiency. Blank and Dorf (2012, pp. 31-49) in Manifest of Customer Development, assert that start-up metrics differ from those of existing enterprises. Applying traditional performance indicators to an enterprise that seeks to confirm its existence is not a suitable picture of reality or their use cannot lead to principal decisions. 
Blank (2013) proposes to replace traditional accounting reports of the income statement, balance sheet, cash flow statement with metrics that more aptly reflect the start-up progress, for example, customer acquisition cost, lifetime customer value, churn, viralness. A start-up that has not yet earned can have a large number of users who can switch to paying customers and paying customers can turn to profitable customers. Non-financial indicators and the rate of their conversion (Ries 2011, p. 123) are temporary and proxy measures of start-up performance. Nevertheless, monetization cannot be completely neglected. According to an analysis by Wagner (2013), 8 out of 10 start-ups fail over 18 months, mainly due to a lack of understanding of customer needs and inadequate generation of revenues. According to the KPMG survey (KPMG 2016), up to 84\% of start-ups consider the growth of sales and revenues to be their priority.

Although the business model of a start-up is considered to be a key condition for viability and business success, its knowledge is inadequate, whereby the model succumbs to changes in a relatively short time. More in-depth understanding of the business model structure and its impact on business performance can contribute to the more deliberate development and less failure of start-up. Successful investor McClure (2017) introduces five key determinants of investment in start-ups: market, product, team, customers and revenue. Apart from the team, the other four conditions are part of the business model. Start-ups need a reliable and effective way how to make money, otherwise their struggle for existence does not make sense and they terminate.

\section{Goal, Research Sample and Methods}

The main goal of the research is to gain an insight into the structure of the business model of start-ups and to deepen its knowledge, as the literature study has shown that the business model is a basic prerequisite for the start-up viability and its potential business successes but this assertion is not supported by an empirical research. The first partial goal is to describe the individual blocks of the business model and to ascertain the degree of their development. The second partial goal is to find out the relationship between the degree of the business model development and its performance. The third partial goal is to find out how effective there is the conversion of the start-up performance indicators.

The goals of the research are based on the working hypothesis that a developed and quality business model is a basic and central prerequisite for the viability and success of the start-up. The hypothesis is tested by the relationship between the degree of development (quality) of the business model and the start-up performance.

Research sample and data collection. The field research was conducted in three stages (October-December 2015, June-July 2016, January-March 2017) and the sample consists of start-ups operating in Bratislava area, where the largest start-up community in Slovakia is concentrated. Estimates of some governmental material indicate that there are about 600 start-ups in Slovakia (Koncepcia pre podporu ekosystému startupov v Slovenskej republike 2016). The startitup portal (Startitup n.d.) displays 301 start-ups. However, these data are not based on official statistics, which does not record start-ups as a special category. According to an estimate of the author of the article, about half of all start-ups in Slovakia are concentrated in Bratislava and its surroundings. Bratislava is the capital of Slovakia with half million inhabitants and center of business (e.g., VW Slovakia with 12,500 employees), education (five public universities and several private colleges) and culture. It is placed by riverside of Danube and is remoted $60 \mathrm{~km}$ from Vienna/Austria, $200 \mathrm{~km}$ from Budapest/Hungary and $330 \mathrm{~km}$ from Prague/Czech republic. However, roughly one-third of all start-ups do not develop any obvious preparatory or business activity. In the first, second and third stages of the survey, the sample contained 76,72 and 53 start-ups. So, the research sample contains a significant number of start-ups operating in the over-developed EU region.

Start-ups are making business according to classification of SK NACE/Nomenclature statistique des activités économiques dans la Communauté européenne (SK NACE 2016) in industries of Information and Communication (29.9\%), Administrative and Support Services (26.6\%), Industrial Production 
(17.7\%), Arts, Entertainment and Recreation (12.2\%), Wholesale and retail trade (6.8\%), Financial and insurance activities (6.8\%). Data are averaged out for the three stages of research.

The sample was put together in consultation with investors and representatives of co-working centers, incubators and accelerators. The selection criterion was an investment by an angel investor or a minimal validation of the start-up on the market that would guarantee a minimum degree of start-up development and a higher probability of its existence during the research period. Each start-up was examined by one member of the research team who personally recorded evaluations and replies of the founder/owner to the closed and open questions in the questionnaire and immediately explained any ambiguities. Structure of published data and scales of points are originated from the questionnaire. Another source of knowledge were interviews with team members, additional interviews as needed, publicly available information about investigated start-ups from their websites, other websites, for example, finstat, startitup and professional journals, which also served for additional checks and corrections.

Variables. For the description and analysis of business models, the canvas method by Osterwalder and Pigneur was chosen (Osterwalder and Pigneur 2009, pp. 15-44). Among the available methods of visualizations of business model, it is the most comprehensive (Slávik 2011). It captures the economic side of business through revenue and cost flows, records points where costs are consumed and revenue generated. It describes the value an enterprise creates for the customer. The applied method of visualization enables effectively to explore a particular enterprise and describe a particular business model. The main blocks of the model are Customer value propositions, Customer segments, Customer relations, Distribution channels, Key partners, Key activities, Key resources, Cost structure and Revenue streams.

Independent variables describing the degree of development of the business model blocks based on the canvas method are shown in Table 3. (ten variables). Variables of Customer Value propositions and Customer segments were divided into two variables. The bipolar interval scale (Gavora 2012, pp. 62-63) was used to measure the variables. It evaluates the different degree of one trait of the studied subject. Rating 1 on the 5 -point scale means "no functionality" and rating 5 means "full functionality." The degree of development of a business model block is measured on a scale of: 1-no, 2-basic concept, 3-complete concept, 4-trails with implementation, 5-complete or almost complete functionality. The content validity of the scale is ensured by the use of the canvas research tool and the unambiguous formulation of development degree.

Dependent variables that measure the business performance of start-up are listed in Table 3a-c (three variables). Start-up performance is measured by the number of users, the number of paying users (customers) and the revenue. The unipolar interval scale was used to measure the variables (Gavora 2012, p. 63). Rating 1 on the 5-point scale means "no performance" and rating 5 means "max performance." The number of users and the number of paying users (customers) are measured on the scale of: 1-none, 2-several (1-10), 3-several tens (11-100), 4-several hundred (101-1000), several thousand and more (1001-10,000). Users are registered/recorded not-paying customers. They have for example, an approach to an app free of charge but they are obliged to register to a provider of services. It is a common business practice of start-ups so that they can attract a huge amount of users and they are converted in paying customers later.

Revenues are measured on a scale of 1 -none, 2-cover current costs from 0 to $25 \%$, 3-cover current costs from 25 to $75 \%$, 4-cover current costs from 75 to $100 \%$, 5-also bring a profit. The use of three metrics to measure the start-up performance corresponds to the nature of a starting and imperfect enterprise whose performance cannot be described by the traditional indicator only, for example, revenues (Ries 2011, pp. 114-48).

The conversion of performance indicators takes place in two degrees: 1 . users $\rightarrow$ customers: number of users (scale 1-5) $\times$ number of customers (scale 1-5), 2. users $\rightarrow$ customers $\rightarrow$ sales: number of users (scale $1-5) \times$ number of customers (scale $1-5) \times$ sales (scale $1-5$ ). Reliability of the scales 
of variables is confirmed by Cronbach's alpha from 0.9 to 0.62 , min. 0.6 and above is considered acceptable (DeVillis 1991).

The analytical procedure consists of descriptive statistics, correlation table and regression models. Descriptive statistic describes the business model through average values, median and standard deviation of the degree of development of its blocks. It provides a comprehensive and also more detailed picture of how the business start-up model is changing and maturing during three stages of research: identification of the degree of development of the business model depending on the development of the business idea, start-up performance depending on the development of the business idea and distribution of start-ups depending on the development of the business idea. The phases of the business development of a start-up are recorded on the scale of business idea development (business cycle): 1-idea, 2-product development, 3-prototype product/testing, 4-min viable product/first revenues, 5-validated product/increasing revenues. To measure the originality of the business idea, the scale was used: 1-local, 2-national, 3-Central European, 4-European, 5-global. Descriptive statistics also describes the efficiency of conversions from users through customers to revenues. The correlation table serves to assess the integrity of the business model. Low correlation coefficient values indicate weak links between model blocks due to their inappropriate structure or ineffective coordination of their blocks.

Regression models investigate causal links based on multiple linear regression that measures the impact of the business model on selected start-up performance indicators. The viability of the start-up is verified using a regression model that identifies statistically relevant relationships between the business model, which is expressed by ten independent variables and its performance, which is expressed by three independent variables. A functioning business model is an essential prerequisite for the success of a start-up and its performance must be measured by several variables due to the different level of model development. The influence of the independent variables is compared to identify independent variables that have a significant effect on the dependent variable being studied. The model is gradually modified to have the structure that best explains the variables examined. For this reason, variables with the smallest and statistically insignificant effects were removed and at the same time, the condition of growth of determination coefficient had to be met. The verifiability of the model for one explanatory variable was evaluated using a determination coefficient and, in the case of several variables, by a modified determination coefficient. The level of $p<0.05$ is considered to be statistically significant. Results with $p<0.05$ are emphasized and discussed only. The regression model serves to confirm or disprove the working hypothesis. If the business model is working and is a basic prerequisite for viability, a link must be proven between a degree of its development and business performance of start-up. Achievement of a performance is a criterion of the maturity and quality of the business model.

\section{Research Results}

\subsection{Description of Elementary Results}

Founders of start-ups are 28 years old on average and have a second degree of university education. Before establishing a start-up and starting independent business making, they were employees for 7.5 years. The average number of team members increased from five and a half to seven during the research and the average time of start-up existence from 22 months to 36 months. The founders had financial resources ranging from 50,000 to 200,000 euros, which should cover approximately a year's start-up operation. The highest cost item was wages (44.5\%).

The originality of the business idea during the research has increased only very slightly (3.76-3.91) and is almost on the European level. Forty-four point four percent (44.4\%) of start-ups affirmed that the originality was verified by market surveys or confirmed by orders. On the other hand, the same share of start-ups declared that a similar product exists somewhere in the world, even surveys, exhibitions 
and own experiences confirmed it. Start-uppers, however, see the originality of their business with higher quality, improvement of product, different design or product adaptation to a particular market.

Start-ups developed their business idea during their research (about 1.5 years) from an advanced prototype (3.66) to first sales/revenues (4.36). At the beginning of the research, they identified the needs and problems of customers at the level of experimentations with their satisfaction (4) and at the end of the research, they improved this knowledge by almost half of the assessment point (4.47). The product passed through verification trials from lower (4.3) to a higher level (4.69). Product development slightly overtook the knowledge of satisfied needs and problems by two to three-tenths of a point. Customers are willing to pay for the convenience which brings them a solution, its novelty and cost savings.

Start-ups get to know their customers and make the first contacts with them (4.11-4.45). They pursue the first attempts to enter the market (4.24-4.75), which extends from Central European up to European territory (3.41-3.59). The knowledge of the customer and the market has been considerably high since the start of research and has not changed dramatically during the research. Start-ups enter foreign markets by a form of direct export (2.15-2.13), thus independently without any intermediaries and there was no change in the considerations about the entry to the foreign market during the research. In most observed cases, there is no more detailed customer differentiation, for example, a typical customer and the most important customer.

Distribution channels are formulated at the beginning of the research as conceptual ideas on a high-level (3.62), which are transformed into implementation attempts (4.16) after approximately one and a half year. Start-ups strongly prefer their own distribution. In the structure of distribution, only minor changes have occurred in favor of indirect own channels. The most popular distribution channels are direct and own ones. These are, particularly, personal meetings. Frequently mentioned channels are also exhibitions or conferences that are an opportunity to build personal contacts.

Development of customer relationships progressed from the advanced conceptual notion (3.84) to the implementation trials (4.40). Initially, the start-ups did not prefer overly any relationship, they mostly considered a partial contact, for example, through online services. Partial contact ultimately accounts for more than one-third of customer relationships at the end of the research. The shares of self-service, personal and extraordinary assistance has fallen slightly and the role of co-creation has increased. If a start-up has some big customers, it prides itself on good relationships and it tries to build personal relationships. If a large number of customers are needed, most start-ups build communities, for example, blogs, discussions and forums to which they contribute with expert articles.

The resources that are necessary for the realization of the entrepreneurial idea were at the beginning of the research mostly in the form of a highly developed conceptual idea (3.91), which at the end of the research turned into trials with a realization (4.48). The most important sources are people who have a 50\% share of all start-up resources. The criterion of importance is the significance of resources for running and meeting the goals of a start-up. People are appreciated for their initiative, ideas, diligence and perseverance. The distribution network recorded the largest increase in the share of all sources from the beginning to the end of the research.

Processes that are necessary for an operation of a start-up and the activation of resources are at the beginning of the research in the state of a developed conceptual notion (3.8) and at the end of the research, they are at a higher level of trials with a realization (4.48). The most significant processes are the realization of the idea, thus the transformation of the idea into a real product or service and then the sale of the finished product. In the course of the research, the decline in the share of the idea realization and the increase in the share of sales and marketing arises, which is accompanied by constant communication with customers in order to obtain feedback and repeated verification of the assumptions. An important process is forming a platform that is a large community of loyal supporters who are using the product and still returning to it.

Potential partners who supply missing resources and processes have improved from a state of the conceptual idea (3.5) to trials with implementation (4.18). At the beginning of the research, the most important partners were investor, merchant and manufacturer. At the end of the research, the most 
important partners were investor, merchant and component supplier. The share of suppliers and implementers fell and the share of traders increased quite significantly. An investor is an important partner if, in addition to money, he/she accelerates processes, gets to start the project and gives the start-up a self-confidence and sureness. Partners are also platforms that serve for sale or promotion of the product.

The cost structure of the future product is compiled from the first to the third stage of research at the level of implementation trials (3.95-4.43). The largest cost item of start-up operation in the first stage of research is wages $(44.48 \%)$, then co-operation $(14.73 \%)$ and material $(12.38 \%)$. These items remained the largest in the next stages of research too and slightly increased by $4.32 \%$. The other costs item significantly decreased from $14 \%$ to $5 \%$.

The largest source of funding in the first stage of research is own savings (more than one third), then own resources (retained earnings and depreciation), strategic investors, venture capital and business angels. In the second, but especially in the third stage, there is a significant change in the structure of funding. Their own resources (retained earnings and depreciation) have almost arisen on one-third and they are the largest source of funding; one-fifth of resources are provided by strategic investors, somewhat less money comes from own savings, more than one-tenth of resources consist of venture capital. There has been a significant drop in own savings from $38 \%$ to $19.62 \%$.

Start-ups have conceptual ideas only about the prices of their products at the start of research (3.8) but at the end of the research, they are trying considerably to make them more concrete (4.40). Somewhat less, they have a concrete notion about the number of products and services sold (3.47-4.06) and the number of users remains only on the conceptual level (3.16-3.88) over the whole observed period. At the beginning of research, there are only first notions (2.62 and 2.47) about the number of customers and at the end of research, they reach behind the threshold of conceptual considerations (3.21 and 3.40). The number of users, the number of customers and the revenues are underdeveloped compared to other business model blocks, this is also a little bit true for the quantity of sold products.

Table 1 shows the strengths and weaknesses of start-up business models and priorities of founders and their teams. The span between the most and the least developed block was shortened during the survey from 1.04 to 0.8 . The most developed block is still a customer value proposition and the least developed block is revenue streams, the largest change during the survey was recorded by partners (0.67 points) and revenue streams (0.67 points). Customer segments (0.36) and key processes (0.37) have changed at least. Distribution, partners and key processes are slightly below-average developed blocks. If the degree of development of the studied block is lower at the start of the research, it remains lower at its end too, there are no signs of growth acceleration. Growth is approximately directly proportional to time.

Table 1. Degree of model blocks development.

\begin{tabular}{ccccccccccc}
\hline Blocks $\downarrow$ & \multicolumn{3}{c}{ Average } & \multicolumn{3}{c}{ Difference } & Median & \multicolumn{3}{c}{ Std. Dev. } \\
\hline Stage of Research $\rightarrow$ & $\mathbf{1 .}$ & $\mathbf{2 .}$ & $\mathbf{3 .}$ & $\mathbf{1 . - 3}$ & $\mathbf{1 .}$ & $\mathbf{2 .}$ & $\mathbf{3 .}$ & $\mathbf{1 .}$ & $\mathbf{2 .}$ & $\mathbf{3 .}$ \\
\hline Customer value proposition & 4.15 & 4.50 & 4.58 & 0.43 & 4.50 & 5.00 & 5 & 0.97 & 0.75 & 0.66 \\
Cost structure & 3.95 & 3.29 & 4.45 & 0.50 & 4.00 & 3.00 & 5 & 1.16 & 1.27 & 1.18 \\
Customer segments & 3.90 & 4.10 & 4.26 & 0.36 & 4.00 & 4.33 & 4 & 0.73 & 0.77 & 0.61 \\
Key resources & 3.91 & 4.32 & 4.43 & 0.52 & 4.00 & 5.00 & 5 & 1.07 & 0.90 & 0.95 \\
Customer relationships & 3.84 & 4.19 & 4.40 & 0.56 & 4.00 & 4.50 & 5 & 1.12 & 1.04 & 0.91 \\
Key processes & 3.80 & 4.17 & 4.17 & 0.37 & 4.00 & 4.00 & 5 & 1.01 & 0.87 & 1.21 \\
Distribution channels & 3.62 & 3.79 & 4.17 & 0.55 & 4.00 & 4.00 & 4 & 1.29 & 1.27 & 1.07 \\
Key partners & 3.50 & 3.79 & 4.17 & 0.67 & 4.00 & 4.00 & 5 & 1.34 & 1.28 & 1.21 \\
Revenue streams & 3.11 & 3.38 & 3.78 & 0.67 & 3.20 & 3.50 & 4 & 1.04 & 1.00 & 0.88 \\
Blocks totally & 3.75 & 3.95 & 4.27 & 0.52 & 3.95 & 4.00 & 4.40 & 0.82 & 0.68 & 0.66 \\
\hline
\end{tabular}

Source: own research data. 
The business model increases the degree of its development with the proceeding phases of the improvement of the entrepreneurial idea but from Table 2a there is evidence that in the first stage of the research the model is already quite developed (it is close to a full concept) and the progress to the last phase does not represent either 1.5 point (slightly above the implementation trials) or the progress between phases one and five is only $33.5 \%$, if 4.25 is $100 \%$, even in phase 2 there is a slight decline in model development and the increment between phases 4 and 5 is minimal. However, according to the number of start-ups, for the research there are focal 3, 4 and 5 stages. In the first two phases, only $14.5 \%$ of the research sample is placed. Progress in developing the business model in all three stages of the research is evident from Table $2 \mathrm{~b}$. Average progress from the first to the third stage is $11.8 \%$ (3.75-4.25, Table 2a).

Table 2. (a) Average degree of business model development in particular phases of business idea development. (b) Relative business model development on the base of business cycle.

(a)

\begin{tabular}{|c|c|c|c|c|c|c|c|}
\hline & \multirow{2}{*}{$\begin{array}{l}\text { Stage of } \\
\text { Research }\end{array}$} & \multicolumn{5}{|c|}{ Cycle of Business Idea-Phases } & \multirow{2}{*}{ Total } \\
\hline & & 1 & 2 & 3 & 4 & 5 & \\
\hline \multirow{3}{*}{ Business model } & 1. & 2.82 & 2.58 & 3.32 & 4.19 & 4.25 & 3.75 \\
\hline & 2. & 3.57 & 2.78 & 3.21 & 4.19 & 4.31 & 3.95 \\
\hline & 3. & - & - & 3.36 & 4.32 & 4.49 & 4.25 \\
\hline \multirow{3}{*}{$\begin{array}{l}\text { Number of start-ups in a phase } \\
\text { of business idea development }\end{array}$} & 1. & 3 & 8 & 20 & 26 & 19 & 76 \\
\hline & 2. & 1 & 3 & 17 & 19 & 32 & 72 \\
\hline & 3. & - & - & 9 & 16 & 28 & 53 \\
\hline
\end{tabular}

Source: own research data.

(b)

\begin{tabular}{cc}
\hline Stage of Research & Progress from Phase $\mathbf{1}$ to Phase $\mathbf{5}$ \\
\hline 1. & $2.82-4.25=\mathbf{3 3 . 5 \%}$ \\
2. & $3.57-4.31=\mathbf{1 7 . 2} \%$ \\
3. & $3.36 / 3$ phase $-4.49=\mathbf{2 5 . 2} \%$ \\
\hline \multicolumn{2}{c}{ Source: own research data. }
\end{tabular}

The business model of the studied start-ups is a compact whole because the relations between its blocks (Appendix A: Table A1) — their tightness is expressed by the correlation coefficient-have relatively high values but with a remarkable tendency. Most of the coefficients from the first to the third stage of research are diminishing, although the degree of block development is growing. The individual quality of the blocks increases but the tightness of the relations between them is being weakened. However, the model works effectively only as a cooperative entity and thus the effect resulting from the development of the blocks is disappearing due to weaker links and the start-up does not reach the performance it could do.

\subsection{Relationship between Business Model and Performance of Start-up}

\subsubsection{First Stage of the Research}

The number of users is relevantly impacted by the ability to identify the right customers and develop distribution channels, both variables together explain $23 \%$ variability of the number of users. The number of customers is statistically relevantly impacted by the perfection of key processes and knowledge (handling, cognition) of the costs structure. Both variables explain $24 \%$ variability of the number of customers. The amount of revenues/sales is statistically relevantly impacted by the perfection of key processes and the knowledge (handling, cognition) of the costs structure. Both variables explain $29 \%$ variability of the amount of revenues/sales. 
The number of users is affected by variables other than the number of customers and the amount of revenues. The number of customers and the amount of revenues are affected by the same variables; however, they have a slightly stronger influence on the revenues/sales than on customers. The identified influential variables do not belong among the blocks of the business model with the highest degree of development, as there is for example, customer value proposition. Details are given in Table 3a.

Table 3. (a) Relationship between business model and start-up performance. 1st stage of research. (b) Relationship between business model and start-up performance. 2nd stage of research. (c) Relationship between business model and start-up performance. 3rd stage of research.

(a)

\begin{tabular}{|c|c|c|c|c|c|c|}
\hline \multirow{2}{*}{ Blocks of Business Model } & \multicolumn{2}{|c|}{ Users } & \multicolumn{2}{|c|}{ Customers } & \multicolumn{2}{|c|}{ Revenues } \\
\hline & Model 1 & Model 2 & Model 1 & Model 2 & Model 1 & Model 2 \\
\hline $\begin{array}{l}\text { 1. a Customer value proposition- } \\
\text { cognition of satisfied needs }\end{array}$ & $\begin{array}{c}0.2 \\
(0.21)\end{array}$ & - & $\begin{array}{c}0.11 \\
(0.21)\end{array}$ & - & $\begin{array}{c}0.05 \\
(0.22)\end{array}$ & - \\
\hline $\begin{array}{l}\text { 1. b Customer value proposition- } \\
\text { degree of product development }\end{array}$ & $\begin{array}{l}-0.20 \\
(0.27)\end{array}$ & & $\begin{array}{c}0.12 \\
(0.28)\end{array}$ & - & $\begin{array}{c}0.23 \\
(0.29)\end{array}$ & - \\
\hline $\begin{array}{l}\text { 2. a Customer segments- } \\
\text { identification of customers }\end{array}$ & $\begin{array}{c}0.38 \\
(0.27)\end{array}$ & $\begin{array}{l}0.39 * \\
(0.18)\end{array}$ & $\begin{array}{l}-0.04 \\
(0.27)\end{array}$ & - & $\begin{array}{l}-0.20 \\
(0.28)\end{array}$ & - \\
\hline $\begin{array}{l}\text { 2. b Customer segments-presence } \\
\text { on the market }\end{array}$ & $\begin{array}{c}0.14 \\
(0.12)\end{array}$ & $\begin{array}{c}0.14 \\
(0.11)\end{array}$ & $\begin{array}{c}0.17 \\
(0.12)\end{array}$ & - & $\begin{array}{l}-0.09 \\
(0.12)\end{array}$ & - \\
\hline 3. Distribution channels & $\begin{array}{l}0.37 * \\
(0.12)\end{array}$ & $\begin{array}{l}0.32 * * \\
(0.13)\end{array}$ & $\begin{array}{c}0.10 \\
(0.16)\end{array}$ & - & $\begin{array}{l}-0.06 \\
(0.17)\end{array}$ & - \\
\hline 4. Customer relationships & $\begin{array}{c}0.28 \\
(0.19)\end{array}$ & - & $\begin{array}{c}0.07 \\
(0.19)\end{array}$ & & $\begin{array}{c}0.06 \\
(0.20)\end{array}$ & - \\
\hline 5. Key resources & $\begin{array}{c}0.00 \\
(0.28)\end{array}$ & - & $\begin{array}{l}-0.17 \\
(0.28)\end{array}$ & - & $\begin{array}{l}-0.06 \\
(0.30)\end{array}$ & - \\
\hline 6. Key processes & $\begin{array}{l}-0.21 \\
(0.28)\end{array}$ & - & $\begin{array}{c}0.38 \\
(0.28)\end{array}$ & $\begin{array}{l}0.40 * \\
(0.18)\end{array}$ & $\begin{array}{c}0.41 \\
(0.29)\end{array}$ & $\begin{array}{l}0.46^{*} \\
(0.19)\end{array}$ \\
\hline 7. Key partners & $\begin{array}{l}-0.10 \\
(0.12)\end{array}$ & - & $\begin{array}{c}0.10 \\
(0.13)\end{array}$ & - & $\begin{array}{c}0.10 \\
(0.13)\end{array}$ & - \\
\hline 8. Costs structure & $\begin{array}{c}0.19 \\
(0.18)\end{array}$ & - & $\begin{array}{c}0.19 \\
(0.18)\end{array}$ & $\begin{array}{l}0.31 * \\
(0.16)\end{array}$ & $\begin{array}{c}0.31 \\
(0.20)\end{array}$ & $\begin{array}{l}0.37 * \\
(0.16)\end{array}$ \\
\hline $\mathrm{R}$ & 0.53 & 0.48 & 0.55 & 0.49 & 0.56 & 0.54 \\
\hline R Square & 0.28 & 0.23 & 0.30 & 0.24 & 0.31 & 0.29 \\
\hline Adjusted R Square & 0.17 & 0.20 & 0.20 & 0.22 & 0.20 & 0.27 \\
\hline Std. Error of the Estimate & 1.25 & 1.23 & 1.26 & 1.24 & 1.33 & 1.27 \\
\hline Sig. & 0.012 & 0.000 & 0.006 & 0.000 & 0.005 & 0.000 \\
\hline
\end{tabular}

In brackets there is std. error. Sig. $<0.05^{*} .<0.01^{* *}$. Source: own research data.

(b)

\begin{tabular}{lcccccc}
\hline \multirow{2}{*}{ Blocks of Business Model } & \multicolumn{2}{c}{ Users } & \multicolumn{2}{c}{ Customers } & \multicolumn{2}{c}{ Revenues } \\
\cline { 2 - 8 } & Model 1 & Model 2 & Model 1 & Model 2 & Model 1 & Model 2 \\
\hline 1. a Customer value proposition- & -0.07 & - & 0 & - & 0.36 & \\
cognition of satisfied needs & $(0.24)$ & & $(0.25)$ & & $(0.28)$ & \\
\hline 1. b Customer value proposition- & -0.43 & -0.35 & 0.08 & - & 0.11 & - \\
degree of product development & $(0.26)$ & $(0.2)$ & $(0.27)$ & & $(0.31)$ & \\
\hline 2. a Customer segments- & 0.09 & - & 0.38 & - & -0.04 & - \\
identification of customers & $(0.27)$ & & $(0.28$ & & $(0.31)$ & \\
\hline 2. b Customer segments-presence & $0.23^{*}$ & $0.22 * *$ & $0.2 *$ & $0.18^{*}$ & -0.07 & - \\
on the market & $(0.1)$ & $(0.09)$ & $(0.1)$ & $(0.09)$ & $(0.11)$ & \\
\hline
\end{tabular}


Table 3. Cont.

\begin{tabular}{|c|c|c|c|c|c|c|}
\hline \multirow{2}{*}{ Blocks of Business Model } & \multicolumn{2}{|c|}{ Users } & \multicolumn{2}{|c|}{ Customers } & \multicolumn{2}{|c|}{ Revenues } \\
\hline & Model 1 & Model 2 & Model 1 & Model 2 & Model 1 & Model 2 \\
\hline 3. Distribution channels & $\begin{array}{c}0.16 \\
(0.17)\end{array}$ & - & $\begin{array}{c}0.22 \\
(0.18)\end{array}$ & - & $\begin{array}{c}-0.07 \\
(0.2)\end{array}$ & - \\
\hline 4. Customer relationships & $\begin{array}{c}0.35 \\
(0.22)\end{array}$ & $\begin{array}{c}0.46^{* *} \\
(0.18)\end{array}$ & $\begin{array}{c}0.34 \\
(0.23)\end{array}$ & $\begin{array}{l}0.7^{* *} \\
(0.12)\end{array}$ & $\begin{array}{l}0.71^{+} \\
(0.26)\end{array}$ & $\begin{array}{c}0.86^{* *} \\
(0.14)\end{array}$ \\
\hline 5. Key resources & $\begin{array}{c}0.01 \\
(0.24)\end{array}$ & - & $\begin{array}{l}-0.21 \\
(0.25)\end{array}$ & - & $\begin{array}{l}-0.07 \\
(0.28)\end{array}$ & - \\
\hline 6. Key processes & $\begin{array}{c}0.02 \\
(0.23)\end{array}$ & - & $\begin{array}{c}-0.02 \\
(0.24)\end{array}$ & - & $\begin{array}{c}-0.08 \\
(0.26)\end{array}$ & - \\
\hline 7. Key partners & $\begin{array}{c}0.03 \\
(0.12)\end{array}$ & - & $\begin{array}{c}-0.01 \\
(0.12\end{array}$ & - & $\begin{array}{l}-0.16 \\
(0.14)\end{array}$ & - \\
\hline 8. Costs structure & $\begin{array}{c}0.33 \\
(0.22)\end{array}$ & $\begin{array}{c}0.37^{+} \\
(0.2)\end{array}$ & $\begin{array}{c}0.13 \\
(0.22)\end{array}$ & - & $\begin{array}{c}0.23 \\
(0.25)\end{array}$ & - \\
\hline $\mathrm{R}$ & 0.63 & 0.62 & 0.65 & 0.61 & 0.65 & 0.6 \\
\hline R Square & 0.39 & 0.38 & 0.42 & 0.37 & 0.42 & 0.36 \\
\hline Adjusted R Square & 0.29 & 0.34 & 0.32 & 0.35 & 0.32 & 0.36 \\
\hline Std. Error of the Estimate & 1.06 & 1.02 & 1.1 & 1.08 & 1.23 & 1.19 \\
\hline Sig. & 0 & 0 & 0 & 0 & 0 & 0 \\
\hline
\end{tabular}

In brackets there is std. error. Sig. $<0.05^{*} .<0.01^{* *} .<0.06<0.07^{+}$. Source: own research data.

(c)

\begin{tabular}{|c|c|c|c|c|c|c|}
\hline \multirow{2}{*}{ Blocks of Business Model } & \multicolumn{2}{|c|}{ Users } & \multicolumn{2}{|c|}{ Customers } & \multicolumn{2}{|c|}{ Revenues } \\
\hline & Model 1 & Model 2 & Model 1 & Model 2 & Model 1 & Model 2 \\
\hline $\begin{array}{l}\text { 1. a Customer value proposition- } \\
\text { cognition of satisfied needs }\end{array}$ & $\begin{array}{l}-0.37 \\
(0.29)\end{array}$ & - & $\begin{array}{l}-0.53 \\
(0.35)\end{array}$ & - & $\begin{array}{l}-0.36 \\
(0.41)\end{array}$ & - \\
\hline $\begin{array}{l}\text { 1. b Customer value proposition- } \\
\text { degree of product development }\end{array}$ & $\begin{array}{c}0.32 \\
(0.38)\end{array}$ & - & $\begin{array}{l}0.08 \\
(0.46)\end{array}$ & - & $\begin{array}{c}0.07 \\
(0.53)\end{array}$ & - \\
\hline $\begin{array}{l}\text { 2. a Customer segments- } \\
\text { identification of customers }\end{array}$ & $\begin{array}{c}0.16 \\
(0.30)\end{array}$ & - & $\begin{array}{c}0.35 \\
(0.36)\end{array}$ & - & $\begin{array}{c}0.33 \\
(0.42)\end{array}$ & - \\
\hline $\begin{array}{l}\text { 2. b Customer segments-presence } \\
\text { on the market }\end{array}$ & $\begin{array}{l}0.39 * \\
(0.11)\end{array}$ & $\begin{array}{c}0.33^{* *} \\
(0.10)\end{array}$ & $\begin{array}{c}0.14 \\
(0.14)\end{array}$ & - & $\begin{array}{c}0.27 \\
(0.16)\end{array}$ & - \\
\hline 3. Distribution channels & $\begin{array}{c}-0.02 \\
0.21\end{array}$ & - & $\begin{array}{l}-0.09 \\
(0.26)\end{array}$ & - & $\begin{array}{c}0.00 \\
(0.30)\end{array}$ & - \\
\hline 4. Customer relationships & $\begin{array}{l}-0.03 \\
(0.25)\end{array}$ & - & $\begin{array}{c}0.54 \\
(0.30)\end{array}$ & $\begin{array}{c}0.55^{* *} \\
(0.19)\end{array}$ & $\begin{array}{c}0.58 \\
(0.35)\end{array}$ & $\begin{array}{l}0.50 * \\
(0.25)\end{array}$ \\
\hline 5. Key resources & $\begin{array}{c}-0.59^{+} \\
(0.32)\end{array}$ & $\begin{array}{l}-0.57 * \\
(0.25)\end{array}$ & $\begin{array}{r}-0.09 \\
(0.38)\end{array}$ & - & $\begin{array}{l}-0.40 \\
(0.44)\end{array}$ & - \\
\hline 6. Key processes & $\begin{array}{l}-0.20 \\
(0.21)\end{array}$ & - & $\begin{array}{r}-0.26 \\
(0.26)\end{array}$ & - & $\begin{array}{l}-0.54 \\
(0.30)\end{array}$ & - \\
\hline 7. Key partners & $\begin{array}{l}0.54 \text { * } \\
(0.17)\end{array}$ & $\begin{array}{c}0.42 * * \\
(0.14)\end{array}$ & $\begin{array}{c}0.37 \\
(0.21)\end{array}$ & - & $\begin{array}{c}0.74^{* *} \\
(0.24)\end{array}$ & $\begin{array}{l}0.45^{*} \\
(0.18)\end{array}$ \\
\hline 8. Costs structure & $\begin{array}{l}0.57 * \\
(0.29)\end{array}$ & $\begin{array}{l}0.41 \text { * } \\
(0.21)\end{array}$ & $\begin{array}{c}0.19 \\
(0.35)\end{array}$ & - & $\begin{array}{c}0.51 \\
(0.40)\end{array}$ & - \\
\hline $\mathrm{R}$ & 0.57 & 0.53 & 0.49 & 0.38 & 0.62 & 0.51 \\
\hline R Square & 0.33 & 0.28 & 0.24 & 0.15 & 0.37 & 0.26 \\
\hline Adjusted R Square & 0.17 & 0.22 & 0.06 & 0.13 & 0.22 & 0.23 \\
\hline Std. Error of the Estimate & 1.04 & 1.01 & 1.26 & 1.22 & 1.46 & 1.45 \\
\hline Sig. & 0.052 & 0.003 & 0.233 & 0.005 & 0.019 & 0.000 \\
\hline
\end{tabular}




\subsubsection{Second Stage of the Research}

The number of users is relevantly influenced by the rate/degree of presence on the market and the tightness of customer relationships; both variables jointly explain $38 \%$ variability of the number of users. The number of customers is statistically relevantly impacted by the rate/degree of market presence and tightness of customer relationships again. The impact of market presence decreased slightly (a lower value of the regression coefficient) and the impact of customer relationships increased more strongly (a higher value of the regression coefficient). Both variables explain $37 \%$ variability of the number of customers. The amount of sales is statistically relevantly impacted by customer relationships only. They explain $36 \%$ of revenues variability.

The number of users and customers are affected by the same variables. Amount of revenues/sales is affected by the only variable out of the previous two variables, namely customer relationships. The identified influential variable of customer relationships belongs among the blocks of the business model with a higher degree of development. Details are given in Table $3 b$.

\subsubsection{Third Stage of the Research}

The number of users is relevantly impacted by the rate/degree of market presence, key resources, partners and cost structure control, these four variables jointly explain $28 \%$ variability of the number of users. The number of customers is statistically relevantly impacted by the customer relationships only that explain $15 \%$ variability of the number of customers. Amount of sales/revenues is statistically relevantly impacted by customer relationships and key partners. Together, they explain $26 \%$ of sales/revenues variability. The number of users is affected by different variables than the number of customers. The amount of sales/revenues is affected by the same variable as the number of customers and the further variable is also relevant to the number of users.

The identified influential variable of customer relationships belongs among the blocks of the business model with a higher degree of development. Details are given in the Table 3c.

The impact of the business model on start-up performance is not the same in all three stages of research. Perhaps most important is to examine the impacts in the last, third stage of the research given that the start-up is evolving, increases the degree of development of blocks of its business model and the improvement of the model should be reflected in its performance, otherwise the whole business effort will be ruination and meaningless or the founders are doing something wrong or incorrectly. Since the start-up is not a fully functional enterprise, all three performance indicators can be considered legitimately, although the ultimate criterion of truth is revenues.

The rate of transmission of a statistically significant impact between the stages of research, when it is somehow naturally expected to reinforce the impact of the factor, is rather low. From this point of view, only the block of customer relations is deserving a respect. It influences all three performance indicators in the second stage of the research and in the third stage, it influences the number of customers and revenues. So, it has good conversion over time (from 2 nd to 3 rd stage) and between different performance indicators too. Reducing the sample from 76 and 72 start-ups to 53 start-ups does not provide evidence of their more purposeful behavior against the background of the business model. Larger and smaller samples show similar behavior.

\subsection{Conversion of Performance Indicators of Start-Up}

Conversion expresses the capability of the start-up to convert users to customers and customers to revenues. The conversion fundamentally reflects the efficiency of the business model and the viability of the start-up. The inability to converge has serious consequences and depreciates otherwise well-functioning business model. The conversion of the research sample is recorded in Table 4 .

The conversion of users to customers is higher at every stage of the research than conversion to customers and customers to revenues. In the third stage of the research, user conversion to customers is approximately $50 \%$ and the conversion from users to revenues is approximately $40 \%$. Conversion 
to customers $(37.64 \%, 41.52 \%, 51.92 \%)$ and conversion to revenues $(24.17 \%, 29.0 \%, 39.54 \%)$ has an increasing tendency across all three research stages.

Table 4. Conversion of start-up performance in three stages of research.

\begin{tabular}{ccccccc}
\hline \multirow{2}{*}{ Indicator } & \multicolumn{2}{c}{ 1st Stage } & \multicolumn{2}{c}{ 2nd Stage } & \multicolumn{2}{c}{ 3rd Stage } \\
\cline { 2 - 7 } & $\begin{array}{c}\text { Users } \rightarrow \\
\text { Customers } \\
\text { Max 25 }\end{array}$ & $\begin{array}{c}\text { Users } \rightarrow \\
\text { Customers } \\
\rightarrow \text { Revenues } \\
\text { Max 125 }\end{array}$ & $\begin{array}{c}\text { Users } \rightarrow \\
\text { Customers } \\
\text { Max 25 }\end{array}$ & $\begin{array}{c}\text { Users } \rightarrow \\
\text { Customers } \\
\rightarrow \text { Revenues } \\
\text { Max 125 }\end{array}$ & $\begin{array}{c}\text { Users } \rightarrow \\
\text { Customers } \\
\text { Max 25 }\end{array}$ & $\begin{array}{c}\text { Users } \rightarrow \\
\text { Customers } \\
\rightarrow \text { Revenues } \\
\text { Max 125 }\end{array}$ \\
\hline Average & 9.41 & 30.21 & 10.38 & 36.25 & 12.98 & 49.43 \\
Median & 9 & 18 & 9 & 26 & 12 & 32 \\
Std. dev. & 7.70 & 34.67 & 7.58 & 36.20 & 7.47 & 41.34 \\
Average/max. conversion (\%) & 37.64 & 24.17 & 41.52 & 29.00 & 51.92 & 39.54 \\
Median/max. conversion (\%) & 36.00 & 14.40 & 36.00 & 20.80 & 48.00 & 25.60 \\
Share of top conversion (\%) & 11.84 & 6.6 & 13.9 & 8.33 & 20.75 & 13.2 \\
Top conversion/total number & $9 / 76$ & $5 / 76$ & $10 / 72$ & $6 / 72$ & $11 / 53$ & $7 / 53$ \\
of start-ups & & & &
\end{tabular}

Source: own research data.

In the first stage of the research, the share of start-ups with the max conversion from users to customers has been $11.84 \%$ (9/76) and from users to customers and to revenues $6.6 \%(5 / 76)$. In the second stage of the research, the share of start-ups with the max conversion from users to customers has been $13.88 \%$ (10/72) and from users to customers and to sales has been $8.33 \%(6 / 72)$. In the third stage of the research, the share of start-ups with the max conversion from users to customers has been $20.75 \%(11 / 53)$ and from users to customers and to revenues has been $13.21 \%(7 / 53)$. Even the share of start-ups with the largest conversion is rising across all three stages of research but a diminishing research sample has to be taken into account.

In the third stage of the research, 15 start-ups had the highest revenues, hence on the level 5 and more. The average degree of business model development of these start-ups was 4.54 . In the third stage of the research, 19 start-ups had the lowest revenues, hence on the level 1 and 2 . The average degree of business model development of these start-ups was 3.73 .

\subsection{Examples of Excellent Conversion}

This chapter contains the choice of six start-ups with the best conversion out of fifteen start-ups with the highest revenues. The descriptions of start-ups are done by author of the article on the basis of his personal observation.

Aerobtec has become known for its technical specialty, which is the altimeter for aviation modelers; later it developed a device to extend the flight of drones by up to $20 \%$. Since the start of its business making, it has decided solely for global action because the domestic market is too small for such specific products. Aerobtec uses distributors to cover as much market space as possible. Representatives are in all major markets. However, the positive responses of individuals from the modelling community brought better results than mass marketing and the market showed a tremendous interest in the product.

Powerlogy is an e-shop selling its own healthy food. Products of Powerlogy are unique in that they have undergone comprehensive development and testing. They are produced only from raw materials that meet the demanding quality criteria. Start-up has given a true picture of trends and inclinations to healthy nutrition at more educated and solvent consumers who are willing to pay more for the higher up to extreme quality. Independent sale through e-shop significantly streamline and facilitate access to a customer and provide direct feedback without disturbing influences.

Sli.do is a start-up and application that enables the involvement interactively of each participant of a conference or lecture in action during an event. The founders knew from the beginning that they had to focus outside of Slovakia. Start-up apparently discovered a completely empty marketplace. An excellent conversion has been supported by international activity from the start of business making and by entering into a large and developed US market that has been backed by a big investment in a distribution building. 
Keygoes:chili offers a simple product in unexpected design. A small container with spice is hanging on a key ring. The uniqueness of the product lies in reconciling functionality and design. A good conversion is facilitated by having their own e-shop, easy penetration abroad and the repeated sale of capsules with a spice.

KickResume is a web application that helps quickly create a good looking CV, cover letter or personal website. The result of using the product is immediately visible (a correctly written curriculum vitae) or with short feedback (e.g., a response from a potential employer), people usually do not economize on themselves if their ego is at stake.

Tripo.sk is a start-up and a portal for people who plan to travel abroad. They need accommodation and are not familiar with foreign cities. Revenues consist of commissions for intermediation of accommodation and air travel. The customer/visitor to the site does not pay for the search and booking, the client at the website of tripo.sk does not feel like a customer, whereby tripo.sk attracts him/her with a large database and travel tips and consulting.

\subsection{Reasons for not Earning Revenues}

The reasons for not earning revenues in the first stage of research are the incomplete product, incomplete operating or manufacturing realization and distribution $(60.7 \%)$. Various other failures are shared in the non-revenues generation to the extent of $26.8 \%$. In the second stage of research, the share of these causes fell to $50.4 \%$ and $19.9 \%$ and in the third stage to $46.2 \%$ but other failures increased to $34.2 \%$. As a new and enough significant reason for non-earning, a constant growth of start-up has emerged with the share of $12.08 \%$ in the sense that building a company takes precedence over capturing revenues. During the three stages of research, the impact of the incomplete product was significantly reduced. Incompletely developed distribution still plays a large and slightly growing role, including its failure and the share of team failure grows. Distribution, operation and the team/people are the most serious reasons for not earning revenues at the last stage of research.

\section{Discussion}

\subsection{Description of Elementary Results}

Surveyed start-ups are young according to the age of founders and the time of their existence, and they are educated and slightly experienced. Youth is a strength, which is expressed in enthusiasm, willingness to take risks, ambitious plans, diligence and at the same time a handicap, which is manifested by limited entrepreneurial experience, lack of knowledge of business operations, an absence of business contacts and considerable lack of own financial resources. In advanced countries, founders enter business making in middle-age and with bigger entrepreneurial experience. The research of American start-ups has shown that the founder of the technology enterprise is 39 years old on average (Education and Tech Entrepreneurship 2009), 92\% of the founders graduated with a first degree of university study and $32 \%$ completed a second degree. The average age of start-up founders in Israel is 34 years (TOUCHIT n.d.). The national business environment in highly developed countries, particularly the long history and tradition of free making business, are a cause of a responsible attitude to making money and therefore business men and women enter the world of the economy older and more experienced in comparison with, for example, Slovakia.

The originality of the business idea of the scrutinized start-ups is almost at the European level, it slightly increased during the survey. The increment can be attributed to the reduction of the research sample and the departure of less excellent start-ups. Proofs of originality are subjective perceptions and assessments that will be confirmed after a longer market presence. An intense encounter with competition seems to weaken this originality. Start-uppers do not pay enough attention to the originality and there are no rare cases when global competitors are discovered till at the phase of high development. Start-up founders are captivated by the notions of novelty and perfection of the product and do not perceive the product through the eyes of the customer. 
Start-ups have a size of a microenterprise. The smallness of start-up is manifested by an incomplete set of resources and processes that are necessary for business making but on the other hand, the microenterprise is dynamic, adaptable and initially inconspicuous too. However, these initial conditions make the start-up by an incomplete and imperfect enterprise.

The homogeneity of the business model (the difference between the most and least developed block is decreasing) is slightly increasing. Some faults, anomalies or interesting practice are apparent on the changes of business model from the 1st to 3rd stage of the research:

- the product development slightly overtakes the knowledge of satisfied needs, although the opposite relation would be more advantageous,

- $\quad$ the market is delimited between Central European and European territory, although for exponential growth there is a more suitable European area at least and global dimension is the best,

- the form of direct entry into the foreign market without intermediaries strongly dominates, which may be a serious barrier against growth in the near future,

- similarly, independent distribution is strongly preferred but it belongs still among the less developed blocks of the business model,

- the earlier notions about the anonymous/self-service sale have been replaced by personal contact with large customers and co-creation,

- the main source is the people (50\% importance), they represent the strength and weakness of the start-up, however, their creativity and hard work can revert to mental, intellectual and physical exhaustion, team cooperation can change to team breakdown,

- the structure of internal resources of start-ups has changed only minimally throughout the research, distribution channels have reinforced its relative importance most out of all the blocks, although absolutely a very moderate only. Stable distribution of resources in an enterprise that is growing rapidly is unusual.

- $\quad$ at the end of the research, the main process is sale and marketing and the share of the idea realization process is reduced, which is natural in trying to monetize the idea but at the same time it indicates somewhat a disposable existence of a start-up,

- at the conclusion of the research, the main partners are the trader and the investor but the partners still belong to the less developed blocks of the business model. Given the limited resources and the very small number of employees, the partners should get a greater scope in the business model. Munoz et al. (2015) on the base of research affirm that those micro-enterprises that were searching for external assistance, especially from other enterprises, are more efficient.

- the largest cost item is wages that are conditioned by the most important source, which is people, whereby the cost structure throughout the research has been relatively stable, which is in a way inconsistent with the development of processes when sale and marketing are getting at the forefront in the third stage of research,

- performance indicators are the least developed variable, revenue streams are lagging behind the development of other blocks, it is expected that they will naturally develop as a consequence of improving other model blocks that will be the natural consequence and outcome of improving the model as a whole as if the sense of revenue streams resided solely in the record of the results, the causes of which lie in other blocks of the model,

- the main cause of non-revenues generation is the uncompleted realization of the product, its share is gradually decreasing and the share of other causes is increasing, thus the number of reasons increases and their individual share decreases, it will obviously pose increased demands for the management and operation of the start-up,

- during the research, it turned out that the development of the blocks of the business model is uneven but the differences are gradually wiping out, however a certain range of differences will be probably the permanent and natural feature of the start-up, 
- the blocks of the model and their interaction/cooperation are two relatively independent entities and young and inexperienced micro-enterprise cannot sufficiently exactly perceive and harmonize them. However, the need for strong internal relations in an enterprise/start-up is also confirmed by the research of Blumberg and Pfann (2016), who state that social capital in the form of strong ties is a better predictor of enterprise than human capital. Analogously, for the research results presented, this means that the quality of relationships within the business model is more important to the performance of start-up than the quality of its blocks.

\subsection{A Relationship between a Business Model and Start-Up Performance}

Independent variables that affect start-up performance (measured by the appropriate indicators) are not very consistent, although relevant findings ultimately relate to the 3 rd stage of research and, in particular, to the revenues indicator. However, it should be taken into account that even after the third stage of the research, the start-up development is not yet complete. The inconsistency of the influential factors (independent variables) can be considered as an objective finding of the first kind and then each stage of the research captures start-ups in a situation where objective ad hoc factors are acting (each stage or each performance indicator have its own influence factors) or an objective finding of the second kind, that has an explanation in chaotic, accidental, hands-on action of start-ups or even to serendipity (Pluchino et al. 2018), although serendipity perhaps comes to those who are well prepared and hard-working. The second explanation may be closer to the truth.

It cannot be overlooked that in the third stage of research, a larger number of statistically influential factors (7) affect all the performance indicators than in 2nd stage (5) and 1st stage (6). It is obviously a consequence of the start-up progress and the need to prove the results. It is worth noting that the most developed block of customer value proposition as the single block of the business model did not show any relevant impact on performance. Regardless of the stage of research, the most of all the relevant factors (8) have effects on users and five factors on customers and five ones on sale.

The relationship between the selected attribute of the company and the indicator of its success was also sought by the study by Löfsten (2016). He found that the long-term survival of the new technology-based firm, which according to the study is identified de facto to start-up, had been significantly affected by the business experience and size of the enterprise (employment). The study by Ammar and Chereau (2018) considers it a research limit if strategy-business model innovation alignments are not investigated along with addressing such alignments from the standpoint of firm performance. These studies hint that looking for a link between the performance of a start-up and its assumptions makes sense, although factors of the business experience and size of the enterprise are not directly related to the business model however they extend the range of relevant factors.

\subsection{Conversion of Start-up Performance Indicators}

Excellent conversion seems to be based on a more advanced business model. The start-ups with the highest revenues have a business model that is more developed by $17.84 \%$ than start-ups with the lowest revenues $(4.54=100 \%, 3.73=82.16 \%)$. This is not an overly big difference but its impact on the performance is consistent with the notion that top performance is the result of relatively small differences between the most and less developed start-ups. To explain this phenomenon, an analogy can be found, for example, in sport, where the differences between top performances and results are minimal, victory is decided about in tenths or hundredths of seconds, thus the differences that are negligible outside the top sport but with huge consequences, for example, victory in the prestigious competition, cash prize, public reputation, advertising earnings. The minimum advance before an opponent at the edge of human possibilities is not only a result of talent and training of a sportsman but also of his/her team support. Achieving extraordinary business success is also the result of many factors and for example, an extraordinary customer value proposition alone is not enough.

The start-ups with maximum conversion have business model blocks of customer relationships and key partners on the highest level of 5 , which is consistent with the regression models in Table 3 . 
The start-ups with the highest revenues have customer relationships at the level of 4.81 and partners at the level of 4.75, which is also consistent with the regression models in Table 3. Start-ups with the lowest revenues have customer relationships at the level of 3.94 and partners at the level of 3.52. According to the examples of the start-ups with the highest conversion, it can be assumed that the conversion is being increased by the simple distribution channel, for example, having their own e-shop, a website that is also a distribution channel and partners who are experienced distributors.

A start-up is a very small enterprise that has many differences compared to a more mature and bigger enterprise, for example, it has very modest and incomplete resources, it is inexperienced and quite closed, high ambitions are not supported by verified proofs, in the process it is expected to bring a huge and exponential growth and multiple valuations of the investment, while the main performance indicator that is revenue depends on a variable set of impacts, the structure of which gives rise to the impression of a chance event. These differences (imperfections) can be overcome only by a highly functional business model in which the missing parts will be complemented by partners (in most blocks) and the founder focuses on transforming his/her idea through the development of business model blocks and their effective coordination.

\section{Conclusions}

Start-uppers know the customer, they know his/her needs but they cannot get to him/her. Start-ups are closed to themselves and are not aware of, or underestimate the need and necessity for, partnerships because, in reality, they have only one valuable asset, which is an entrepreneurial idea and the second asset of questionable quality and excellence is the business model in a semi-finished state. Monetization is not just an expression of business performance in monetary units. It is a special expertise in looking for or generating sources of earnings and converting them into money. Factors affecting the business performance of a start-up are unstable and variable in a relatively short time and the only relevant conclusion is that the business model is an obvious and confirmed determinant of business performance, although the impact of its blocks does not conduct according to a steady scheme.

The business model of start-ups does not develop its blocks equally. Throughout the field research, the block of customer value proposition was the most developed and the block of revenues was the least developed; the blocks of customer segments and key processes were improved the least. The blocks of distribution, partners and key processes remained below-average developed blocks. If the degree of development of the surveyed block was lower at the beginning of the research, it remained at its conclusion too-there were no signs of accelerating level. The improvement of the business model structure is approximately proportional to the time of start-up existence. The range between the most developed and the least developed block slightly shortened during the research.

Start-ups try to develop mostly the block of business customer value proposition but this block does not show a statistically relevant impact on the performance. The impact of individual business model blocks on performance has been variable throughout the research and only the customer relationship block seems to have a more considerable and stable impact but start-uppers do not pay the most attention to this block.

Excellent conversion is mainly supported by business model blocks of customer relationships and key partners. Conversion is greatly improved by having their own distribution channel of a start-up.

The start-ups with the best results are those that have managed to get close to the customer, whereby an attractive customer value proposition is a matter of course. Then there are those who are winning who are skilled in marketing and the conversion of an interest and satisfaction of customer needs into money. Further research should, therefore, focus on the distribution, effective coordination of business model blocks, partnership building and monetization secrets.

Funding: This research was funded by the Scientific grant agency of Ministry of Education of Slovak Republic and Slovak Academy of Sciences (VEGA), grant number 1/0019/15.

Conflicts of Interest: The author declares no conflict of interest. 
Appendix A

Table A1. Correlation of blocks of business model/correlation matrix in three stages of research.

\begin{tabular}{|c|c|c|c|c|c|c|c|c|c|c|c|c|}
\hline & & & CVP & CS & DCh & CR & KR & KPro & KPart & RS & CS & $\mathrm{ABM}$ \\
\hline $\begin{array}{l}\text { 1. customer value } \\
\text { proposition }\end{array}$ & PC & $\begin{array}{l}\text { 1. stage } \\
\text { 2. stage } \\
\text { 3. stage }\end{array}$ & 1 & & & & & & & & & \\
\hline $\begin{array}{l}\text { 3. distribution } \\
\text { channels }\end{array}$ & PC & $\begin{array}{l}\text { 1. stage } \\
\text { 2. stage } \\
\text { 3. stage }\end{array}$ & $\begin{array}{l}0.59 * \\
0.64 \text { * } \\
0.46^{*}\end{array}$ & $\begin{array}{l}0.56^{*} \\
0.52^{*} \\
0.16\end{array}$ & 1 & & & & & & & \\
\hline $\begin{array}{l}\text { 4. customer } \\
\text { relation-ships }\end{array}$ & PC & $\begin{array}{l}\text { 1. stage } \\
\text { 2. stage } \\
\text { 3. stage }\end{array}$ & $\begin{array}{l}0.66 \text { * } \\
0.60 \text { * } \\
0.53 \text { * }\end{array}$ & $\begin{array}{l}0.44^{*} \\
0.57 \text { * } \\
0.39 \text { * }\end{array}$ & $\begin{array}{l}0.5^{*} \\
0.69 \text { * } \\
0.41^{*}\end{array}$ & 1 & & & & & & \\
\hline 5. key resources & PC & $\begin{array}{l}\text { 1. stage } \\
\text { 2. stage } \\
\text { 3. stage }\end{array}$ & $\begin{array}{l}0.73 \text { * } \\
0.75 \text { * } \\
0.53 \text { * }\end{array}$ & $\begin{array}{l}0.62 \text { * } \\
0.52 \text { * } \\
0.35 \text { * }\end{array}$ & $\begin{array}{l}0.58 \text { * } \\
0.59 \text { * } \\
0.48 \text { * }\end{array}$ & $\begin{array}{l}0.53 \text { * } \\
0.55 \text { * } \\
0.73 \text { * }\end{array}$ & 1 & & & & & \\
\hline 8. key partners & PC & $\begin{array}{l}\text { 1. stage } \\
\text { 2. stage } \\
\text { 3. stage }\end{array}$ & $\begin{array}{l}0.31 \text { * } \\
0.36 \text { * } \\
0.29 \text { * }\end{array}$ & $\begin{array}{l}0.36^{*} \\
0.33^{*} \\
0.11\end{array}$ & $\begin{array}{l}0.35 \text { * } \\
0.53 \text { * } \\
0.42 \text { * }\end{array}$ & $\begin{array}{l}0.26 \text { * } \\
0.37 \text { * } \\
0.44 \text { * }\end{array}$ & $\begin{array}{l}0.23 \\
0.33 \text { * } \\
0.52 \text { * }\end{array}$ & $\begin{array}{l}0.31 \text { * } \\
0.36 \text { * } \\
1.00 \text { * }\end{array}$ & 1 & & & \\
\hline $\begin{array}{l}\text { 9. revenues } \\
\text { streams }\end{array}$ & PC & $\begin{array}{l}\text { 1. stage } \\
\text { 2. stage } \\
\text { 3. stage }\end{array}$ & $\begin{array}{l}0.63 \text { * } \\
0.60 \text { * } \\
0.39 \text { * }\end{array}$ & $\begin{array}{l}0.61 \text { * } \\
0.63 \text { * } \\
0.49 \text { * }\end{array}$ & $\begin{array}{l}0.57 \text { * } \\
0.69 \text { * } \\
0.35 \text { * }\end{array}$ & $\begin{array}{l}0.59 \text { * } \\
0.75 \text { * } \\
0.61 \text { * }\end{array}$ & $\begin{array}{l}0.54 \text { * } \\
0.52 \text { * } \\
0.47 \text { * }\end{array}$ & $\begin{array}{l}0.65 \text { * } \\
0.47 \text { * } \\
0.49 \text { * }\end{array}$ & $\begin{array}{l}0.4 \text { * } \\
0.33 \text { * } \\
0.49 \text { * }\end{array}$ & 1 & & \\
\hline 10. costs structure & PC & $\begin{array}{l}\text { 1. stage } \\
\text { 2. stage } \\
\text { 3. stage }\end{array}$ & $\begin{array}{l}0.65 \text { * } \\
-0.14 \\
0.30 \text { * }\end{array}$ & $\begin{array}{l}0.53 \text { * } \\
0.22 \\
0.08\end{array}$ & $\begin{array}{l}0.48 \text { * } \\
-0.08 \\
0.25\end{array}$ & $\begin{array}{l}0.56 \text { * } \\
-0.01 \\
0.28 \text { * }\end{array}$ & $\begin{array}{l}0.63 \text { * } \\
-0.16 \\
0.25\end{array}$ & $\begin{array}{l}0.63 \text { * } \\
-0.08 \\
0.05\end{array}$ & $\begin{array}{l}0.36 \text { * } \\
0.03 \\
0.05\end{array}$ & $\begin{array}{l}0.63 \text { * } \\
-0.09 \\
0.26\end{array}$ & 1 & \\
\hline $\begin{array}{l}\text { aggregated } \\
\text { business model }\end{array}$ & PC & $\begin{array}{l}\text { 1. stage } \\
\text { 2. stage } \\
\text { 3. stage }\end{array}$ & $\begin{array}{l}0.84^{*} \\
0.77^{*} \\
0.65^{*}\end{array}$ & $\begin{array}{l}0.73 \text { * } \\
0.77 \text { * } \\
0.43 \text { * }\end{array}$ & $\begin{array}{l}0.75^{*} \\
0.83^{*} \\
0.67^{*}\end{array}$ & $\begin{array}{l}0.75^{*} \\
0.81^{*} \\
0.78^{*}\end{array}$ & $\begin{array}{l}0.81 \text { * } \\
0.73 \text { * } \\
0.79 \text { * }\end{array}$ & $\begin{array}{l}0.81^{*} \\
0.68^{*} \\
0.77^{*}\end{array}$ & $\begin{array}{l}0.55^{*} \\
0.63^{*} \\
0.77^{*}\end{array}$ & $\begin{array}{l}0.82 \text { * } \\
0.78 \text { * } \\
0.73 \text { * }\end{array}$ & $\begin{array}{l}0.8 \text { * } \\
0.16 \\
0.43 \text { * }\end{array}$ & 1 \\
\hline
\end{tabular}

PC—Pearson's coefficient, Sig. $<=0.05$, 1st stage $\mathrm{N}=76$, 2nd stage $\mathrm{N}=72$, 3rd stage $\mathrm{N}=53$. Source: own research data. 


\section{References}

Adrodegari, Federico, Andrea Bacchetti, Nicola Saccani, Aitor Arnaiz, and Thomas Meiren. 2018. The transition towards service-oriented business models: A European survey on capital goods manufacturers. International Journal of Engineering Business Management 10: 1-10. [CrossRef]

Afuah, Alan. 2014. Business Model Innovation. New York and London: Routledge.

Ako podporit' startupový ekosystém na Slovensku. 2015. Available online: https://www.podnikajte.sk/startpodnikania/c/2113/category/podpora-podnikania/article/podpora-startupoveho-systemu.xhtml (accessed on 15 November 2016).

Ammar, Oussama, and Philippe Chereau. 2018. Business model innovation from the strategic posture perspective: An exploration in manufacturing SMEs. European Business Review 30: 38-65. [CrossRef]

Blank, Steve. 2013. Why the lean start-up changes everything. Harvard Business Review 91: 63-72.

Blank, Steve, and Bob Dorf. 2012. The Start-up Owner's Manual. The Step-by-Step Guide for Building a Great Company. Pescadero: K\&S Ranch Publishing Division.

Block, Joern H., Karsten Kohn, Danny Miller, and Katrin Ullrich. 2014. Necessity Entrepreneurship and Competitive Strategy. IZA Discussion Papers, No. 8219. Bonn: Institute for the Study of Labour (IZA), pp. 1-32.

Blumberg, Boris F., and Gerard A. Pfann. 2016. Roads Leading to Self-Employment: Comparing Transgenerational Entrepreneurs and Self-Made Start-Ups. Entrepreneurship Theory and Practice 40: 335-57. [CrossRef]

Booming Berlin. 2016. A Closer Look at Berlin's Start-up Scene. Research Study. Berlin: Institut für Strategieentwicklung (IFSE).

CB Insights. 2016. The Top 20 Reasons Start-Ups Fail. CB Insights. Available online: https://www.cbinsights.com/ research-reports/The-20-Reasons-Startups-Fail.pdf (accessed on 15 November 2016).

Davila, Antonio, George Foster, Xiaobin He, and Carlos Shimizu. 2015. The rise and fall of start-ups: Creation and destruction of revenue and jobs by young companies. Australian Journal of Management 40: 6-35. [CrossRef]

Dent, Robert C., Fatih Karahan, Benjamin Pugsley, and Aysegul Şahin. 2016. The Role of Start-ups in Structural Transformation. Staff Report. New York: Federal Reserve Bank of New York, No. 762.

DeVillis, Robert. 1991. Scale Development: Theory and Application. Newbury Park: Sage.

Education and Tech Entrepreneurship. 2009. Available online: https://www.kauffman.org/what-we-do/research/ 2009/04/education-and-tech-entrepreneurship (accessed on 15 November 2016).

Euchner, Jim, and Abhijit Ganguly. 2014. Business Model Innovation in Practice. A systematic approach to business model innovation can help capture value and reduce risks. Research-Technology Management 57: 33-39.

Foss, Nicolai J., and Tina Saebi. 2017. Fifteen Years of Research on Business Model Innovation: How Far Have We Come and Where Should We Go? Journal of Management 43: 200-27. [CrossRef]

Fritsch, Michael, and Michael Wyrwich. 2018. Regional knowledge, entrepreneurial culture and innovative start-ups over time and space-An empirical investigation. Small Business Economics 51: 337-53. [CrossRef]

Gassmann, Oliver, Karolin Frankenberger, and Michaela Csik. 2014. The Business Model Navigator. London: Pearson.

Gavora, Peter. 2012. Tvorba výskumného nástroja pre pedagogické bádanie. (Creation of Research Instrument for Educational Exploration). Bratislava: SPN.

Gimpel, Henner, Daniel Rau, and Maximilian Röglinger. 2017. Understanding FinTech start-ups—A taxonomy of consumer-oriented service offerings. Electron Markets 28: 245-64. [CrossRef]

Groesser, Stefan, and Niklas Jovy. 2016. Business model analysis using computational modelling: a strategy tool for exploration and decision-making. Journal of Management Control 27: 61-88. [CrossRef]

Hyytinen, Ari, Mika Pajarinen, and Petri Rouvinen. 2015. Does innovativeness reduce start-up survival rates? Journal of Business Venturing 30: 564-81. [CrossRef]

Johnson, Mark W., Clayton M. Christensen, and Henning Kagermann. 2008. Reinventing Your Business Model. Harvard Business Review 86: 51-59.

Klačmer Čalopa, Marina, Jelena Horvat, and Maja Lalić. 2014. Analysis of financing sources for start-up companies. Management 19: 19-44.

Koch, Oliver. 2015. Business Model Development in IT Start-ups-The Role of Scarcity and Personalization in Generating User Feedback. Paper presented at Twenty-Third European Conference on Information Systems (ECIS), Münster, Germany, May 26-29; ECIS 2015 Completed Research Papers, Paper 107. pp. 1-18. 
Kollmann, Tobias, Christoph Stockman, Jana Linstaed, and Julia Kensbock. 2015. European Start-up Monitor 2015. Berlin: German Start-ups Associations.

Kollmann, Tobias, Christoph Stockman, Jana Linstaed, and Julia Kensbock. 2016. European Start-up Monitor 2016. Berlin: German Start-ups Associations.

Koncepcia pre podporu ekosystému startupov v Slovenskej republike. 2016. Conception for the Support of Start-ups in Slovak Republic. Available online: http://www.rokovania.sk/Rokovanie.aspx/BodRokovaniaDetail? idMaterial=24603 (accessed on 11 June 2016).

Kopera, Sebastian, Eva Wsendybył-Skulska, Joanna Cebulak, and Sebastian Grabowski. 2018. Interdisciplinarity in tech start-ups development-Case study of 'UniStartApp' project. Foundations of Management 10: $23-32$. [CrossRef]

Korhonen, Heidi M. E., Kaisa Still, Marko Seppanen, Miika Kumpulainen, Arho Suominen, and Katri Valkokari. 2017. The Core Interaction of Platforms: How Start-ups Connect Users and Producers. Technology Innovation Management Review 7: 17-29. [CrossRef]

KPMG. 2014. Prieskum slovenského startup ekosystému. (Survey of Slovak Start-Up Ecosystem). Bratislava: KPMG na Slovensku.

KPMG. 2016. Start-up Ecosystem Survey Slovakia 2016. Bratislava: KPMG in Slovakia.

Löfsten, H. 2016. Organisational capabilities and the long-term survival of new technology-based firms. European Business Review 28: 312-32. [CrossRef]

Malmström, Malin, and Jeaneth Johansson. 2017. Practicing Business Model Management in New Ventures. Journal of Business Models 5: 1-13.

McClure, David. 2017. Bringing Silicon Valley to Latin America. Available online: https://www.slideshare.net/ dmc500hats (accessed on 12 November 2017).

Munoz, J. Mark, Dianne H. B. Welsh, Sow Hup Chan, and Peter V. Raven. 2015. Microenterprises in Malaysia: a preliminary study of the factors for management success. International Entrepreneurship and Management Journal 11: 673-94. [CrossRef]

Osterwalder, Alexander, and Yves Pigneur. 2009. Business Model Generation. Self published. Amsterdam: Modderman Drukwerk.

Osterwalder, Alexander, Yves Pigneur, Greg Bernarda, and Alan Smith. 2014. Value Proposition Design. Hoboken: John Willey and Sons.

Pettersen, Inger B., Jarle Aarstad, Øystein S. Høvig, and Anita. E. Tobiassen. 2016. Business incubation and the network resources of start-ups. Journal of Innovation and Entrepreneurship 5: 1-17. [CrossRef]

Pluchino, Alessandro, Alessio E. Biondoy, and Andrea Rapisardaz. 2018. Talent vs. Luck: The Role of Randomness in Success and Failure. Available online: https://arxiv.org/abs/1802.07068 (accessed on 20 February 2018).

Ries, Erik. 2011. The Lean Start-up. New York: Crown Business.

Robehmed, Natalie. 2013. What Is A Startup? Available online: https://www.forbes.com/sites/natalierobehmed/ 2013/12/16/what-is-a-startup/\#63eaace54044 (accessed on 15 November 2016).

Rydehell, Hana, and Anders Isaksson. 2016. Initial Configurations and Business Models in New Technology-based firms. Journal of Business Models 4: 63-83.

Sedlacek, Petr, and Vincent Sterk. 2014. The Growth Potential of Start-ups over the Business Cycle. CFM Discussion Paper Series, CFM-DP2014-3; London: Centre for Macroeconomics.

SK NACE. 2016. Štatistická klasifikácia ekonomických činností. (Statistical Classification of Economic Activities). Available online: https://www.financnasprava.sk/_img/pfsedit/Dokumenty_PFS/Podnikatelia/ Clo_obchodnytovar/EORI/StatistickaKlasifikaciaEkonomickychCinnosti.pdf (accessed on 15 July 2019).

Slávik, Štefan. 2011. Komparatívna analýza podnikatel'ských modelov. (Comparative analysis of business models). Scientific journal of Faculty of Businesss Management. University of Economics in Bratislava. Ekonomika a manažment. (Economy and Management) 3: 23-43.

Startitup. n.d. Available online: https://www.startitup.sk/ (accessed on 15 March 2017).

Teece, David J. 2018. Business models and dynamic capabilities. Long Range Planning 51: 40-49. [CrossRef]

Teece, David J., and Greg Linden. 2017. Business models, value capture and the digital enterprise. Journal of Organization Design 6: 1-14. [CrossRef]

Thiel, Peter. 2014. Zero to One. Notes on Start-ups or How to Build the Future. New York: Crown Business.

TOUCHIT. n.d. Available online: https://touchit.sk/liahen-pre-startupy-tel-aviv/36346 (accessed on 15 November 2016). 
Truban, Michal. 2016. Available online: https://m.facebook.com/michal.truban/posts/10209058253989372 (accessed on 15 November 2016).

Van Weele, Marijn, Frank J. Rijnsoever, Chris P. Eveleens, Henk Steinz, Niels van Stijn, and Menno Groen. 2016. Start-EU-up! Lessons from International incubation practices to address the challenges faced by Western European start-ups. The Journal of Technology Transfer 43: 1161-89. [CrossRef]

Wagner, Eric T. 2013. Five Reasons 8 out of 10 Business Fail. Available online: http://www.forbes.com/sites/ ericwagner/2013/09/12/five-reasons-8-out-of-10-businesses-fail/\#5e1536415e3c (accessed on 3 November 2016).

WIKIPEDIA. n.d. Available online: https://sk.wikipedia.org/wiki/Startup (accessed on 15 November 2016).

(C) 2019 by the author. Licensee MDPI, Basel, Switzerland. This article is an open access article distributed under the terms and conditions of the Creative Commons Attribution (CC BY) license (http://creativecommons.org/licenses/by/4.0/). 